\title{
Analisa Politik Keberadaan PMC Academi dalam Konflik Amerika Serikat dan Iraq Tahun 2004-2007
}

\author{
Restu Rahmawati, Axl Papilaya \\ Universitas 17 Agustus 1945 Jakarta \\ restu.rahmawati3@gmail.com,axlpapilaya96@gmail.com
}

\begin{abstract}
Abstrak
Tulisan ini akan membahas tentang analisis politik dari adanya keberadaan PMC Academi dalam Konflik Amerika Serikat dan Iraq, penulis memilih tema ini karena melihat bahwa adanya aroma bisnis dan kepentingan politik dari keberadaan PMC yang ada di Konflik Amerika Serikat dan Iraq tahun 2004-2007. Metode Penelitian yang digunakan adalah kualitatif deskriptif dengan pendekatan studi kasus.. Hasil penelitian menunjukkan bahwa pendiri PMC Academi yakni Price dan Clark keduanya diketahui memiliki hubungan kedekatan dengan elit politik dan pemerintahan di Amerika Serikat saat itu. Hal inilah yang menjadi alasan kuat untuk menyatakan adanya kepentingan khusus diantara PMC Academi dan Pemerintah Amerika Serikat, sehingga tak heran mereka selalu hadir dalam setiap konflik Amerika khususnya di Iraq tahun 2004-2007. Kiprah PMC Academi dan PMC yang lain didukung oleh kebutuhan AS dan negara barat lain yang khususnya membutuhkan SDA seperti minyak bumi dan gas alam dikarenakan untuk mendapatkan itu, semua negara tersebut membutuhkan konflik dan perang dengan segala macam alasan.
\end{abstract}

Kata Kunci: PMC Academi, Konflik Amerika Serikat dan Iraq

\section{A. Pendahuluan}

Tulisan ini akan membahas tentang analisis politik dari adanya keberadaan PMC Academi dalam Konflik Amerika Serikat dan Iraq, penulis memilih tema ini karena melihat bahwa adanya aroma bisnis dan kepentingan politik dari keberadaan PMC yang ada di Konflik Amerika Serikat dan Iraq tahun 2004-2007, khususnya oleh Academi yang diketahui memiliki sejarah khusus dengan pemerintahan Amerika Serikat.

Seperti yang kita ketahui perkembangan politik global dewasa ini juga diwarnai dengan kemunculan korporasi bisnis militer yang lebih akrab dikenal dengan Private Military Company (PMC) yang menyediakan jasa pelayanan tentara bayaran atau tentara swasta, pengawalan, keamanan hingga membangun infrastruktur 
disebuah Negara atau wilayah tertentu, yang banyak digunakan oleh Negara-negara, utamanya Negara maju seperti Amerika Serikat, Inggris, Prancis sebagai sarana pencapaian politik luar negerinya. Aktifitas-aktifitas PMC ini banyak dijumpai pada daerah-daerah yang menjadi ladang konflik seperti Afrika, Amerika Latin dan Timur Tengah.

Private Military Company atau Perusahaan Mliter Swasta mungkin adalah hal baru yang terdengar di telinga kita, namun orang awam hanya mengenal PMC dalam batasan sebuah tentara bayaran. Penyedia Jasa Keamanan atau Penyedia Militer ini sebenarnya mereka tidak mau disebut sebagai tentara bayaran atau mercenaries karena para kontraktor atau pemilik perusahaan ini menganggap bahwa kerja mereka profesional dan lebih meluas serta spesifik. PMC sendiri dalam Buku Carlos Ortiz yang berjudul Private Armed Forces and Global Security $^{l}$ di definisikan sebagai legally established international firms offering services that involve the potential to exercise force in a systematic way and by military or paramilitary means, as well as the enhancement, the transfer, the facilitation, the deterrence, or the defusing of this potential, or the knowledge required to implement it, to clients atau dalam bahasa sederhanya adalah sebuah perusahaan yang menyediakan pelayanan berkaitan dengan militer atau paramiliter yang diberikan dalam bentuk sebuah fasilitas yang disesuaikan keinginan seseorang yang menyewa mereka.

Jadi, dapat kita lihat bahwasanya PMC sendiri hanya akan patuh sesuai keinginan klien atau orang yang menyewa mereka saja. Blackwater atau yang kita kenal sekarang adalah Academi adalah salah satu PMC yang sangat terkenal dan cukup disegani dalam dunia militer swasta, karena teknologi yang mereka pakai sangat canggih dan kita juga mengenal kiprah mereka khususnya saat masih menjadi Blackwater di konflik Irak. Ada satu fakta menarik tentang keberadaan PMC yang selalu ada disetiap konflik dan peperangan yang di lakukan Amerika Serikat dan sekutunya. PMC dalam hal ini kebetulan memang baru berkembang pesat di Amerika dan Eropa saja. Sebut saja konflik Irak, Konflik Suriah, dan

\footnotetext{
${ }^{1}$ http://www.privatemilitary.org/definition.html diakses pada tanggal 11 Desember 2016 pukul 15.30 WIB
} 
hingga Konflik melawan ISIS ( Iraq Syria Islamic State) mereka selalu dilibatkan, bahkan Konflik yang sempat terjadi di Ukraina juga mereka ikut hadir.

Kawasan yang terkenal dengan sumber daya energi minyak dan gas ini merupakan tempat operasi militer yang banyak dijumpai aktifitas para tentara bayaran khususnya dari Amerika Serikat. Di Afganistan misalnya, menjelang akhir tahun 2001 dunia dikejutkan oleh aksi teroris Al Qaeda yang menyerang Amerika bahkan pertahanan terkuat nomor satu di dunia ini mampu ditembus oleh serangan teroris. Peristiwa ini membuat Amerika semakin memperketat penjagaan terhadap aksi-aksi teroris, membuat arah politik menjadi pengalihan isu tentang teroris, serta upayaupaya pendudukan militer dengan alasan bertujuan untuk memerangi terorisme global (global war on terorism) terhadap Islam fundamental dan kawasan timur tengah.

Padahal kita ketahui bahwa AS memiliki jumlah tentara yang sangat banyak dilansir pada tahun 2016 saja AS memiliki Tentara Aktif 1.400.000 personel dan Tentara Cadangan 1.100 .000 personel $^{2}$, tetapi mengapa tetap menggunakan PMC dalam bala bantuan tentara perangnya. Dalam usaha-usaha penawaran jasa militer inilah yang membuat Amerika lebih menggunakan jasa militer swasta dalam melakukan invasi atau hanya untuk melindungi kilang-kilang minyak bahkan pengamanan terhadap tokoh-tokoh penting Amerika yang membutuhkan perlindungan, karena memiliki nilai dan keuntungan yang sangat besar bagi perusahaan tersebut. Disisi lain ternyata hubungan pemilik korporasi militer swasta ini dengan para pejabat tinggi AS memiliki hubungan erat dan keterkaitan dalam politik, pemilik Blackwater (Xe Service LLC) Erik Prince, merupakan seorang pengusaha kaya yang memiliki kedekatan dengan Partai Republik, kakak wanita Erik, Besty DeVos menjadi ketua Partai Republik Michigan dari 1996 sampai

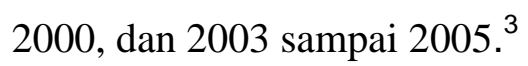

Dalam penelitian ini, penulis akan membatasi pada keberadaan PMC Academi atau Blackwater pada saat ikut dalam Konflik Amerika Serikat dengan Iraq, karena dalam konflik tersebut sangat terlihat jelas keikutsertaan PMC

\footnotetext{
${ }^{2}$ http://chromler.com/blog/10-negara-dengan-militer-terkuat-di-dunia/ diakses tanggal 9 Desember 2016 pukul 17.30 WIB

${ }^{3}$ Jeremy Scahill. 2010. BLACKWATER Membongkar Keterlibatan Tentara Bayaran Dalam Invasi Militer Amerika Serikat. Bandung: PT Mizan Pustaka. hlm. 47
} 
Academi dalam konflik tersebut Maka dari latar belakang tersebut penulis akan mencoba melihat relasi antara Amerika Serikat dan PMC Academi dalam bentuk tulisan yang berjudul "Analisa Politik terhadap Keberadaan PMC Academi dalam Konflik Amerika Serikat dan Iraq Tahun 2004-2007”

Tujuan dari penulisan ini adalah untuk memberi informasi bahwa ada tujuan lain terhadap keberadaan PMC Academi dalam Konflik Amerika Serikat dan Iraq Tahun 2004-2007.

\section{B. Kerangka Teori}

\section{Teori Konflik}

Konflik merupakan gejala sosial yang serba hadir dalam kehidupan sosial, sehingga konflik bersifat inheren artinya konflik akan senantiasa ada dalam setiap ruang dan waktu, dimana saja dan kapan saja. Istilah "konflik" secara etimologis berasal dari bahasa Latin "con" yang berarti bersama dan "fligere" yang berarti benturan atau tabrakan. ${ }^{4}$ Pada umumnya istilah konflik sosial mengandung suatu rangkaian fenomena pertentangan dan pertikaian antar pribadi melalui dari konflik kelas sampai pada pertentangan dan peperangan internasional.

Dalam KBBI, Konflik artinya percekcokan, perselisihan dan pertentangan. ${ }^{5}$ Sedangkan Coser mendefinisikan konflik sebagai suatu perjuangan terhadap nilai dan pengakuan terhadap status yang langka, kemudian kekuasaan dan sumber-sumber pertentangan dinetralisir atau dilangsungkan atau dieliminir saingannya. ${ }^{6}$ Coser lebih menekankan Konflik pada perjuangan untuk mendapatkan sebuah kekuasaan atau sumber yang menjadi kunci terjadinya konflik tersebut. Lain lagi dengan Soerjono Soekanto, konflik yaitu proses pencapaian tujuan dengan cara

\footnotetext{
${ }^{4}$ Setiadi,Elly. 2011. Pengantar Sosiologi Pemahaman Fakta dan Gejala Permasalahan Sosial: Teori, Aplikasi, dan Pemecahannya. Jakarta: Kencana Prenada Media Group. hlm 345.

${ }^{5}$ Kamus Besar Bahasa Indonesia. 2005. Jakarta: Balai Pustaka hlm.587.

${ }^{6}$ Irving M. Zeitlin. 2002. Memahami Kembali Sosiologi. Yogyakarta: Gajah Mada University Press. hlm. 156
} 
melemahkan pihak lawan, tanpa memperhatikan norma dan nilai yang berlaku. $^{7}$

Dari beberapa pengertian tadi, dapat disimpulkan konflik adalah pertentangan atau percekcokan yang didasarkan perjuangan untuk mendapatkan kekuasaan ataupun sumber yang diinginkan dari pihak yang bersangkutan dengan cara melemahkan lawan tanpa melihat norma dan nilai yang berlaku. Dalam penelitian ini, penulis ingin melihat bahwa konflik perang antara Amerika Serikat dan Iraq pada 2004-2007 disebabkan untuk memperebutkan suatu sumber yang dianggap penting bagi kedua belah pihak.

\section{Analisa Politik}

Dalam memecahkan atau melihat suatu permasalahan melalui pandangan Ilmu Politik tentu harus menggunakan sebuah analisa berdasarkan ilmu politik pula. Menurut David E After, untuk menunjukan konsistensi atau integritas dari ilmu politik maka akan ditelusuri enam analisa politik atau wadah dasar pemikiran yang menjadi tema utama ilmu politik yaitu filsafat politik, paham kelembagaan, paham tingkahlaku, paham kemajemukan, paham struktural dan paham perkembangan. ${ }^{8}$ Dari enam analisa politik tersebut, penulis akan menggunakan dua analisa yakni paham tingkahlaku dan paham perkembangan

Dengan mengambil individu selaku manusia politik sebagai satruan dasar pengamatan, perhatian utama paham tingkahlaku terletak pada bagaimana orang bertingkah laku dan apa yang mendorong tingkahlaku mereka. ${ }^{9}$ Jadi, analisa ini ingin melihat sebuah tindakan seseorang didasari atas suatu hal atau apa yang menyebabakan seseorang atau aktor melakukan hal tersebut apakah atas dasar suatu kepentingan.

\footnotetext{
${ }^{7}$ Soerjono Soekanto. 2003. Kamus Sosiologi.Jakarta: PT. Raja Grafindo Persada hlm 99

${ }^{8}$ E. Apter, David. 1996. Pengantar Analisa Politik. Jakarta: LP3ES hlm 7

${ }^{9}$ Ibid 8
} 
Sedangkan Paham Perkembangan merupakan sebuah terapan baru dalam pengkajian ilmu politik. Paham Perkembangan yang merupakan paham baru dalam terapan pengkajian ilmu politik berusaha menelaah pertumbuhan, industrialisasi, dan perubahan serta dampaknya terhadap bentuk pemerintahanserta kebijaksanaan-kebijaksanaannya. Disamping masalah-masalah dalam negeri, perubahan-perubahan yang merupakan perkembangan dunia meliputi konflik-konflik kekuasaan yang terjadi antara dunia pertama atau dunia indsutri demokratis, dunia ketiga atau dunia industri sosialis dan dunia ketiga atau dunia yang sedang berkembang. ${ }^{10}$

Dari penjelasan tersebut, Paham Perkembangan lebih melihat kajian politik pada suatu yang luas dan dinamis mengikuti perubahan serta perkembangan dunia atas kekuasaan dan konflik yang terjadi di ruang lingkup negara-negara di dunia. Dua analisa diatas cukup jelas untuk membantu penulis dalam membahas penelitian ini yakni dengan melihat PMC Academi dan Negara Amerika Serikat sebagai aktor yang memiliki tingkah laku khusus untuk menggapai kepentingan yang mereka miliki yang nantinya akan dipadukan analisis paham perkembangan yang lebih mengacu pada perkembangan dunia atas kekuasaan dan konflik yang memang menjadi latar tempat dari dua aktor tersebut.

\section{Perusahaan Militer Swasta (Private Military Company)}

Dalam kajian politik keamanan kita mengenal istilah aktor-aktor keamanan, dimana aktor keamanan sendiri terbagi menjadi dua jenis yakini aktor keamanan negara, seperti yang kita kenal dengan militer, polisi dan intelijen serta aktor keamanan non-negara yang salah satunya termasuk adalah perusahaan militer swasta atau PMC. (PMC, Private Military Companies) didefinisikan sebagai perusahaan-perusahaan swasta yang mengkhususkan dirinya pada keterampilan militer, yang

\footnotetext{
${ }^{10}$ Op.Cit 9
} 
mencakup operasi tempur, perencanaan strategis, pengumpulan intelijen, dukungan operasional, logistik, pelatihan, pengadaan dan perawatan senjata dan peralatan. Hal tersebut menyiratkan bahwa klien-klien mereka biasanya para pemerintah, tetapi dapat terdiri dari para pemberontak, kelompok-kelompok milisi dan fraksi-fraksi bersenjata lainnya. ${ }^{11}$

Organisasi Kerja Sama Ekonomi dan Pembangunan - Komite Bantuan Pembangunan (OECD-DAC, Organisation for Economic Cooperation and Development - Development Assistance Committee) mendefinisikan Perusahaan Militer dan Keamanan Swasta (PMSC) sebagai 'perusahaan komersial yang secara langsung menyediakan jasa perlindungan militer atau jasa yang berkaitan dengan keamanan untuk mendapat keuntungan, apakah secara domestik atau secara internasional. $^{12}$

Para PMC bisa menyediakan jasa hanya untuk pasar domestik atau beroperasi secara global. PSC domestik biasanya menawarkan jasa penjagaan statis dan perlindungan pribadi bersenjata maupun tidak bersenjata tetapi juga peralatan teknis seperti kamera tv sirkuit tertutup (CCTV, Closed Circuit TV) dan sistem-sistem tombol panik. Jasa ini paling sering ditemukan di dunia berkembang dan negara-negara transisional, tetapi semakin meningkat di dunia berkembang. Sekarang, di Afrika Selatan, jumlah perusahaan ini melebihi polisi dalam bilangan, dan pasar untuk layanan keamanan swasta adalah yang paling besar di seluruh dunia sebagai presentase produk domestik bruto. Sampai bulan Juni 2004, 3.553 PSC didaftarkan di negara tersebut. Sampai bulan Maret 2007 PMC itu mempekerjakan 301.584 'petugas keamanan aktif'

\footnotetext{
11 Sabrina, Schulz .2008. Perusahaan Militer dan Swasta dan Gender. Jakarta: DCAF, OSCE/ODIHR, UN-INSTRAW hlm 2

${ }^{12}$ Organisation for Economic Co-operation and Development (OECD).2007.OECD DAC

Handbook on Security System Reform, Supporting Security and Justice. Paris:OECD Publishing hlm 211
} 
sedangkan kurang lebih 116.000 polisi berseragam melakukan fungsi polisi untuk Kepolisian Afrika Selatan. ${ }^{13}$

Sebagai pembanding, para PMC internasional dengan markas besar atau kantor di beberapa negara menawarkan apa yang sering disebut 'premium protective security services' (jasa keamanan premium) di lingkungan-lingkungan yang berisiko tinggi dalam skala global. Biasanya karyawan PMSC tersebut berlatar belakang militer atau penegakan hukum serta memiliki pengalaman substansial di lingkunganlingkungan yang umumnya disebut 'lingkungan bermusuhan". ${ }^{14}$

\section{Pembahasan}

PMC Academi sebenarnya sudah berdiri jauh lama, namun dahulu kala saat itu memiliki nama Blackwater. Dalam buku Jeremy Scahill dijelaskan profil singkat Blackwater itu sendiri dengan judul buku Blackwater: Membongkar Keterlibatan Tentara Bayaran dalam Invasi Amerika Serikat. Tertulis bahwa ${ }^{15}$ Blackwater terkenal didirikan oleh seorang bernama Eric Prince. Rancangan Blackwater bukanlah berasal dari Prince tapi datang dari mentornya di Tim 8 SEAL, Al Clark, seorang pelatih penggunaan senjata api terbaik di unit tersebut. Ketika Prince memulai karier militernya pada 1993, Clark sudah mengerjakan cetak biru tentang Blackwater. Ide ini muncul karena Clark prihatin Angkatan Laut yang paling dibanggakan di Amerika tak memiliki tempat latihan untuk menembak sehingga harus meminjam dari Marinir atau Angkatan Darat.

Clark punya ide tapi tak mempunyai uang. Dia tidak menduga kalau salah satu orang terkaya yang pernah mengabdi dalam angkatan bersenjata di Amerika akan menjadi muridnya. Pada 1996, Clark dipindahkan ke Tim 8 SEAL dimana Letnan Erik Prince berada di dalam tubuh peleton pertama yang dilatih Clark.

\footnotetext{
13 Minaar, A.2007.Oversight and Monitoring of Non-State/Private Policing: Dealing with Misconduct, Use of Force and Criminal Activities by Private Security Practitioners in South Africa', Regulation of the Private Security Sector in Africa. Pretoria:Institute for Security Studies hlm 17-18

${ }^{14}$ Mancini, F.2005. In Good Company? The Role of Business in Security Sector Reform. London : Demos hlm 44

${ }^{15}$ Lihat http://historia.id/buku/blackwater-tentara-bayaran-paman-sam ditulis oleh Jurnalis Hendri F Isnaeni pada tahun 2010 diakses tanggal 31 Desember 19.23 WIB
} 
Setelah mendapat bekal perang dari Clark, Prince berangkat untuk tugas perang dalam Tim 8 SEAL.

Tujuh bulan kemudian, Clark baru tahu kalau Prince tak hanya memiliki banyak uang tapi juga memilki minat besar pada dunia pelatihan militer swasta. Prince menyelesaikan tugasnya lebih cepat, karena ayahnya, Edgar Prince, mendadak meninggal dunia. Pada 22 Juli 1996, satu tahun lebih setelah kematian dari Edgar Prince, keluarga menjual seluruh perusahaan Edgar kepada seorang milyarder bernama Johnson Controls sebesar \$1,35 milyar tunai. Dengan uang ini Prince berhasil membangun kerajaan bisnisnya sendiri, dengan menggabungkan kecintaannya yang amat mendalam di berbagai aspek seperti religi, politik, dan militer.

"Saya ingin tetap behubungan dengan dunia militer, karena itu saya membangun sebuah fasilitas yang dapat menyediakan tempat berkualitas bagi militer Amerika dan asing yang bersahabat, penegak hukum, dunia komersial, dan organisasi-organisasi dalam mempersiapkan diri mereka untuk pergi ke dalam misi-misi berbahaya," kata Prince.

Blackwater lahir tak lama setelah militer di Amerika Serikat menjalankan privatisasi secara massal, yang diprakarsai Menteri Pertahanan Dick Cheney pada 1989 sampai 1993, di bawah pemerintahan Presiden George H.W. Bush. Blackwater berhasil mencapai kejayaan setelah Amerika melancarkan "perang melawan teror dan kediktatoran" terhadap Irak pada 2003. Kebutuhan Amerika akan tentara semakin banyak, dan Blackwater menyediakannya. Dalam keadaan ini Prince telah lupa diri. Dia mengklaim bahwa dirinya sendiri otak pembentukan Blackwater sehingga menimbulkan reaksi dari sebagian rekannya yang membantunya pada awal pembentukan Blackwater. Situs perusahaan dengan bangga telah menyebut: "Pendiri kami adalah seorang mantan anggota SEAL Angkatan Laut Amerika” Clark, sang pemilik ide telah dilupakan.

Dalam waktu kurang dari satu dekade, Blackwater tumbuh menjadi semacam tentara sewaan bagi usaha pemerintahan Presiden Bush. Saat ini, Blackwater telah memiliki lebih dari 23 ribu tentara swasta yang berada di sembilan negara, termasuk Amerika sendiri. Blackwater memiliki database berisi 21 ribu nama anggota Pasukan Khusus, tentara, dan agen-agen penegak hukum 
yang telah pensiun dan sewaktu-waktu dapat dipanggil kembali. Blackwater memiliki armada angkatan perang seperti lebih dari 20 pesawat, termasuk helikopter yang bersenapan mesin, dan divisi pesawat tempur pengintai. Blackwater mengoperasikan divisi intelijen sendiri, dipimpin eksekutif senior yang merupakan mantan pejabat militer dan intelijen di CIA.

Kantor pusat Blackwater seluas hampir delapan ribu meter persegi di Moyock, Carolina Utara, merupakan fasilitas militer swasta terbesar yang pernah ada di dunia. Di sana terdapat ribuan agen federal dan penegak hukum lokal, di samping tentara-tentara dari negara asing yang "bersahabat", dilatih setiap tahunnya. Baru-baru ini Blackwater membangun fasilitas latihan baru di California (Blackwater West) dan Illinois (Blackwater North), serta sebuah hutan tropis Asia fasilitas latihan di Filipina. Blackwater memiliki nilai kontrak senilai lebih dari \$500 juta dengan pihak pemerintah Amerika, jumlah tersebut tak termasuk dana rahasia untuk operasi-operasi agen-agen intelijen Amerika, korporasi atau individu swasta, dan pemerintah asing.

Dari laman website resmi PMC Academi hanya dijelaskan sekilas mengenai arah dan ranah bidang dimana perusahaan itu berjalan dan layaknya sebuah bentuk pemasaran bagi siapa yang ingin memesan tenaga jasa mereka, berikutlah profile yang diambil dari laman resmi mereka: ${ }^{16}$

Sekilas Perusahaan, Academi adalah penyedia layanan keamanan elit dengan instruktur mampu menciptakan kurikulum pelatihan komprehensif bagi pemerintah dan komersial klien yang memanfaatkan fasilitas perdana 7.000 pelatihan yang terletak di Moyock, North Carolina, Amerika Serikat.

Sejarah Perusahaan, Perusahaan menggabungkan lebih dari lima belas tahun pengalaman dan etos yang diperoleh dari evolusi perusahaan dari keluarga Blackwater perusahaan dan pendahulu ke Xe, dan dari Xe ke Academi.-

Bidang spesialisasi:

- Perlindungan Infrastruktur Kritis

- Maritime Security

- Teknologi Keamanan

${ }^{16}$ Lihat https://www.academi.com/pages/about-us di akses tanggal 30 Desember 2016 Pukul 18.00 
- Logistik

- Sistem Pesawat tak berawak

- Jasa Komersial dan Jasa Pemerintah

- Perlindungan Tinggi Ancaman

- Medis

- Penilaian Risiko \& Ancaman

- Analisis Intel

- Pelatihan Militer dan Paramiliter

Demikianlah profil singkat dari PMC Academi yang sebelumnya bernama Blackwater dimana memiliki historis tersendiri khususnya dengan adanya keterlibatannya dengan pemerintahan Amerika Serikat saat itu.

\section{Latar Belakang Konflik Amerika Serikat dan Iraq}

Sebelum menganalisa tentang keberadaan PMC Academi dalam konflik Amerika Serikat dan Iraq, alangkah terlebih dahulu mengetahui latar belakang konflik yang terjadi sehingga menjadi awal mula dari penulisan penelitrian ini. Konflik senjata antara AS (Amerika Serikat) dengan Irak pada tahun 2003, ada tiga tujuan yaitu AS ingin menghancurkan senjata pemusnah massal, menyingkirkan dunia dari ancaman teroris internasional dan memerdekakan rakyat Irak dari penindasan rezim Saddam Hussein dengan cara memulihkan demokrasi di Irak.

Dari tiga alasan tentang masalah Irak yang harus diselesaikan dengan cara politis damai ternyata dipenuhi kebohongan, yaitu : Agresi AS ke Irak untuk memusnahkan senjata pemusnah massal adalah upaya AS untuk membohongi masyarakat dunia internasional. Dikatakan oleh Presiden George W. Bush bahwa Irak tengah mempunyai senjata pemusnah atau destruksi massal (Weapons of Mass Destruction) yang berupa:

- senjata kimia seperti mostar yang dapat menyebabkan kulit melepuh, tabun dan sarin yang dapat menyerang syaraf manusia.

- Senjata biologi seperti botulinum yang dapat meracuni dan mencekik orang, bacillus antraxis yang dapat menyebabkan penyakit antrax, 
senjata nuklir dan rudal scud yang mempunyai jangkauan 900

kilometer untuk meluncurkan senjata-senjata tersebut.

Untuk meyakinkan rakyat dan kongres di Amerika, Presiden Bush di depan Kongres ketika menyampaikan laporan tahunan menyatakan bahwa Saddam Hussein telah berupaya mengusahakan untuk membeli lima ratus ton uranium oksida dari Nigeria. Dengan demikian kepemilikan dari senjatasenjata tersebut dapat membahayakan rakyat Irak dan negara-negara sekitarnya. Serangan AS ke Irak dengan alasan pemusnahan senjata pemusnah massal sungguh tidak masuk akal, karena bila AS memang ingin menghancurkan senjata itu, Presiden Bush tidak mengerahkan semua kekuatan militernya. AS (dan sekutunya Inggris) hanya mengerahkan 135.000 tentara saja.

Dari jumlah itu, hanya 90.000 prajurit AS dan 45.000 prajurit tentara Inggris yang merupakan pasukan tempur. Sebelum terjadi serangan ke Irak, Tim Inspeksi PBB yang diketuai Hans Blix telah menyatakan sama sekali tidak menemukan bukti Irak memiliki senjata pemusnah masal dan ternyata jangkauan senjata rudal Irak tidak seperti yang dikatakan AS yaitu 900 kilometer, tetapi hanya 10 sampai 15 kilometer.

Menggempur Irak atas nama memerangi terorisme yang didengungkan AS tidak dapat diterima begitu saja dengan bulat-bulat. Tudingan Washington bahwa Bahgdad memiliki hubungan dengan al-Qaidah, organisasi yang sangat dibenci dan sekaligus ditakuti AS sangatlah tidak masuk akal. Di satu sisi, al-Qaidah adalah organisasi yang ingin menggulingkan pemerintahan berpaham liberal maupun sekuler, sementara Partai Baath yang merupakan pimpinan Saddam Hussein tidak memiliki paham fundamentalisme seperti halnya al- Qaidah. Bahkan, rezim Saddam Hussein sendiri termasuk yang harus dihancurkan oleh Al-Qaidah karena merupakan berseberangan paham (pemerintahan Saddam Hussein berpaham sekuler, sedangkan al-Qaidah berpaham fundamentalis yang memegang teguh ajaran Islam). 
Di Irak, meskipun AS mengatakan Saddam Hussein sebagai diktator, tetapi rakyat Irak (kecuali suku Kurdi) sangat mengelu-elukan Saddam Hussein sebagai sosok yang berani mempertahankan kedaulatan Irak dari serbuan AS dan sekutunya. Saat menghadapi invasi AS, Saddam Hussein telah menyerukan kepada rakyatnya agar tetap siaga menghadapi agresi dari personil militer AS. Seruan itu disambut rakyat yang menyatakan akan membela pemimpinnya mati-matian, yaitu Saddam Hussein dan membela tanah Irak.

Dalam pengakuannya, AS selalu mengatakan bahwa serangannya ke Irak untuk menegakkan prinsip demokrasi, tetapi setelah rezim Saddam Hussein jatuh, AS akan kesulitan membangun sebuah pemerintahan baru yang demokratis. Hal ini disebabkan: (1) Prinsip AS sendiri tidaklah demokratis, melainkan berdasarkan pada kepentingan politik nasionalnya saja, yaitu mencegah munculnya penguasa yang menentang kekuasaan, atau berafiliasi dengan negara yang menjadi musuh AS; (2) Pemimpin baru yang dipilih AS untuk memimpin Irak tidak mempunyai basis pendukung yang kuat di kalangan rakyat Irak. Dari kisah ini saja dapat kita lihat bahwa dalam konflik ini sudah dilatar belakangi kepentingan bisnis dari pihak Amerika Serikat dengan cara memfitnah dari Irak itu sendiri.

\section{Analisa Politik Keberadaan PMC Academi dalam Konflik Amerika Serikat dan Irqa Tahun 2004-2007}

Pada bagian ini akan di bahas mengenai analisa politik yang sudah disesuaikan dengan teori yang telah ditentukan sebelumnya yakni memandang PMC Academi sebagai aktor yang memiliki tingkah laku tersendiri bersama dengan Amerika Serikat yang dilanjutkan dengan analisis paham perkembangan dimana keduaa aktor ini bermain yakni perkembangan dunia atas dasar kekuasaan dan konflik. Pemilik PMC Academi atau Blackwater (Xe Service LLC) Erik Prince, merupakan seorang pengusaha kaya yang memiliki kedekatan dengan Partai Republik, kakak wanita Erik, 
Besty DeVos menjadi ketua Partai Republik Michigan dari 1996 sampai 2000, dan 2003 sampai 2005.

Pentagon bertahun-tahun telah menjalin hubungan dengan perusahaan militer swasta ini dan berusaha menutupi kerjasama ini, kerena Pentagon telah menyerahkan kontrak kemiliteran senilai 300 trilliun dollar kepada 12 dari 24 PMC yang bermarkas di Amerika Serikat. ${ }^{17}$ Nama Blackwater sendiri mulai digadanggadangkan beberapa saat setelah terjadinya serangan terhadap Markas Pentagon dan Gedung WTC. Bakal tersohornya nama dari Blackwater sudah tercium saat Donal Rumsfeld selaku Menteri Pertahanan di bawah Presiden George W. Bush menyatakan kepada pers tentang perlunya mengundang para pengusaha atau kontraktor untuk berkiprah di dunia pengelolaan mesin perang, sehari sebelum terjadinya Peristiwa 11 September.

Dalam buku Kapitalisme dan Blackwater karangan Andhini ${ }^{18}$ lebih pada aspek basis-basis bisnis militer yang berada di Irak yang dilakukan oleh PMC, catatan khusus bagi tiga PMC yang tengah beroperasi di Irak pada tahun 2003 adalah Halliburtons, DynCorps, dan Blackwater merupakan PMC yang meraup keuntungan yang sangat amat besar dari invasi militer AS ke Irak ini, dari ketiga PMC tersebut memliliki tugas masing-masing, dan mendapat keuntungan yang tidak sedikit dari operasi yang dilakukan di Irak saat itu.

Selain ketenaran dan popularitas dari Blackwater sendiri, terdapat masalah yang pernah menimpa perusahaan ini yakni adanya kasus penembakan anggota mereka terhadap warga sipil di Irak sehingga menyebabkan warga sipil tersebut tewas. ${ }^{19}$ Ternyata bukan hanya itu saja, dalam sebuah kabar dikatakan bahwa ada hubungan antara CIA dengan Blackwater dalam kasus invasi Amerika terhadap Irak. Dimana di ketahui Eric Prince salah satu pendiri Blackwater adalah anggota kehormatan CIA

\footnotetext{
${ }^{17}$ Jeremy, Scahill .2010.Blackwater:Membongkar Keterlibatan Tentara Bayaran dalam Invasi Amerika Serikat.Jakarta:Mizan hlm. 48

${ }^{18}$ Achmad Muflichin dalam Skripsi Penggunaan PMC dalam Invansi Amerika Serikat Ke Iraq Tahun 2003 hlm. 9

${ }^{19}$ Lihat http://www.cnnindonesia.com/internasional/20141023103550-134-7583/tentarablackwater-bersalah-bunuh-warga-irak/ diakses tanggal 7 Desember 2016 pukul 17.30 WIB
} 
dengan Lencana Hijau yang memperbolehkannya mengakses penuh pangkalan CIA dan bertemu dengan petinggi CIA.$^{20}$

Berita ini kian berkembang sejalan dengan salah para pendiri Blackwater yang ikut turut terjun dalam dunia politik AS dengan memihak salah satu sayap partai dimana dalam CNN Indonesia disebutkan Clark yang telah meninggalkan perusahaan diketahui kerap menyumbangkan dana untuk politisi-politisi Partai Republik, sementara Prince kini menjadi miliarder partai sayap kanan. ${ }^{21}$ Jadi, sebenarnya ada misi khusus atau sisi lain dalam setiap penggunanaan PMC dalam sebuah peperangan, padahal kita ketahui bahwa AS memiliki jumlah tentara yang sangat banyak dilansir pada tahun 2016 saja AS memiliki Tentara Aktif 1.400 .000 personel dan Tentara Cadangan 1.100.000 personel $^{22}$, tetapi mengapa tetap menggunakan PMC dalam bala bantuan tentara perangnya.

Dari pemberitaan itu saja dapat dilihat adanya konspirasi terselubung antara pemilik modal kontraktor khususnya PMC dengan Pemerintah AS. Dalam hal terbaru yakni saat kini masa perang AS dan sekutu dengan ISIS atau Kelompok yang menginginkan pembentukan negara islam di dunia, dimana AS dan sekutu juga turut menurunkan PMC Academi. ${ }^{23}$ Sebenarnya pada tahun 2003, PMC Academi dikontrak hanya untuk menjaga aset negara pada saat invasi Irak, tetapi pada tahun 2004 adanya kontrak baru yang berisikan tentang keikutsertaan PMC Academi untuk ikut turun langsung dalam serangan di Irak. ${ }^{24}$

Dalam invasi ke Irak, Amerika Serikat menggunakan PMC dalam operasi militer yang dilakukan. Porsi pasukan PMC yang ikut turun dalam

\footnotetext{
${ }^{20}$ Op.cit hlm 102

${ }^{21} \mathrm{http} / / / \mathrm{www} . c n n i n d o n e s i a . c o m / i n t e r n a s i o n a l / 20141024112048-134-7793 /$ tentara-bayaranberkedok-petugas-keamanan/ diakses tanggal 7 Desember 2016 pukul 17.30 WIB

${ }^{22} \mathrm{http}$ ///chromler.com/blog/10-negara-dengan-militer-terkuat-di-dunia/ diakses tanggal 9 Desember 2016 pukul 17.30 WIB

${ }^{23}$ Lihat http://international.sindonews.com/read/928218/43/tentara-bayaran-inggris-habisi-8militan-isis-per-hari-1416804323 diakses tanggal 9 Desember 2016 pukul 19.30 WIB

${ }^{24}$ Jeremy, Scahill .2010.Blackwater:Membongkar Keterlibatan Tentara Bayaran dalam Invasi Amerika Serikat.Jakarta:Mizan hlm.144
} 
invasi di Irak terbilang cukup besar. Sebesar 50\% dari total jumlah pasukan tentara yang dikirim dalam invasi ke Irak merupakan personil dari PMC. ${ }^{25}$

Kita dapat melihat bahwa ada bisnis dibalik ini semua, pertama PMC Academi awalnya adalah sebuah perusahaan penyedia persenjataan canggih, dimana bukan hanya satu-satunya perusahaan yang ada di AS atau dunia barat sana tetapi sangat banyak dan jika ada perizinan legal ini akan menjadi perusahaan yang sah, sehingga hukum persaingan pasar sangat terjadi dalam perdagangan senjata di AS, dalam hal ini para kontraktor tersebut mencoba untuk mengajukan berbagai senjata dengan teknologi tinggi mereka kepada negara AS ataupun negara lain yang membutuhkan. Tercatat sementara terdapat ada 62 PMC di dunia yang di dominasi AS dan Inggris. $^{26}$

Singkatnya, yang namanya orang ingin berjualan apalagi dalam bentuk persenjataan mereka butuh lahan ujicoba untuk membuktikan kecanggihan peralatan mereka di mata dunia agar negara lain tertarik untuk membeli atau bermitra dengan perusahaan tersebut. Sehingga, hemat penulis menganggap bahwa konflik yang mengikutsertakan PMC Academi salah satu tujuan pertamanya adalah sebagai ajang unjuk gigi sistem teknologi persenjataan mereka yang akan ditunjukan kepada negara lain, atau mungkin mereka layaknya orang yang berjualan memberikan tester yang digunakan oleh militer AS terlebih dahulu karena hanya militer resmi yang diperbolehkan menggunakan senjata untuk menyerang lawan.

Hal ini diperkuat dengan adanya hubungan pendiri Blackwater yang ikut terjun dalam dunia politik AS seperti pernyataan yang sudah dijelaskan sebelumnya, sudah pasti ada kepentingan terselubung yang ia tawarkan kepada pemerintah AS. Bahkan, sudah menjadi rahasia umum bahwa

\footnotetext{
${ }^{25}$ Tegar Punang Mahardi dalam Skripsi Analisa Penggunaan Private Military Companies (PMCs) Oleh Amerika Serikat Pada Studi Kasus Invasi Amerika Serikat ke Irak Tahun 2009-2011 UMM: Malang hlm. 7

${ }^{26}$ lihat http://www.globalsecurity.org/military/world/para/pmc-list.htm diakses tanggal 9 Desember 2016 pukul 19.30 WIB
} 
banyak politisi di AS atau pengisi kader partai ataupun pendukung dari Presiden yang ingin maju dalam pemilihan di AS kebanyakan dari pengusaha kontraktor bisnis ini.

Kedua, dalam kaum pengusaha atau para kapitalis yang ada dalam tujuan hidup mereka adalah keuntungan terus menerus dengan majunya terus perusahaan mereka, atau bahasa mudahnya mereka akan mencoba segala cara agar bisnis mereka tetap terus ada sampai kapanpun. Penggunaan PMC dalam invasi ke Irak merupakan bisnis militer terbesar. Apalagi di era Neoliberal ini dimana ada pergeseran bisnis dalam aktor negara menjadi aktor non-negara. Menurut Stockholm International Peace Research Institute, ada 100 Perusahan manufaktur senjata di dunia yang berhasil meraup keuntungan jika digabungankan sekitar \$ 402.000.000.000 senjata berhasil dijual pada 2013, ini membuktikan bahwa konflik perang bisa menguntungkan bagi perusahaan di industri persenjataan. ${ }^{27}$ Dalam kurun waktu 2003 hingga 2007 pemerintah Amerika Serikat sudah menganggarkan sebanyak 85 miliar USD yang diberikan pemerintah kepada $\mathrm{PMC}^{28}$

PMC dalam hal ini akan terus ingin eksis kiprahnya dengan memproduksi persenjataan dan penggunaan kekuatan militernya dalam medan peperangan. Maka, bangkrutlah mereka jika negara di dunia selalu damai dan tak ada konflik atau pertikaian, dengan kata lain tidak akan mungkin ada PMC lagi, tidak akan adalagi produk persenjataan lagi yang mereka produksi jika negara di dunia damai. Dengan kata lain, mereka butuh konflik dan perang agar bisnis mereka tetap lancar. Mustahil maka apabila tidak akan pernah ada peperangan yang terjadi di dunia.

Hal ini dapat kita lihat, PMC dikatakan berkembang pesat setelah runtuhnya Gedung WTC tanggal 11 September 2001 atau yang kita kenal dengan istilah 911. Mengapa? karena setelah saat itu AS menyatakan perang terhadap terorsime terkhusus yanng dituduh adalah Al-Qaeda yakni Osama

\footnotetext{
${ }^{27}$ http://tribunindo.com/10-perusahaan-manufaktur-senjata-terbesar-di-dunia/ diakses tanggal 9 Desember 2016 pukul 19.00 WIB

${ }^{28}$ Hannah, Jones. 2011. State Control Over Private Millitary and Security Companies in Armed Conflict. hlm.36
} 
Bin Laden sebagai pimpinannya, disinilah awal mula dari peran PMC digunakan oleh AS seperti yang disebutkan diawal ada hubungan PMC Academi khususnya dengan CIA dalam kasus pencarian dari Laden di Afganistan. Setelah itu berlanjut dengan adanya isu kepemilikan senjata pemusnah massal yakni di Irak dengan Saddam Hussein saat itu dianggap sebagai diktator ${ }^{29}$, dan kembali lagi perang yang dimulai tahun 2004 ini AS menggunakan peran dari para PMC. Dimana saat itu PMC Academi turut ikut dalam peperangan ini. Dapat disimpulkan jika dikaitkan dengan analisis sebelumnya yang mengatakan PMC Academi akan terus ada jika konflik ada dan memang akan terus ada karena pemerintah AS sendiri mendukung mereka karena AS sendiri membutuhkan minyak dan gas alam dari negara yang mereka serang dengan alasan teroris dan demokratisasi itu.

\section{Kesimpulan dan Saran}

Dari hasil penelitian diatas diketahui bahwa pendiri PMC Academi yakni Price dan Clark keduanya diketahui memiliki hubungan kedekatan dengan elit politik dan pemerintahan di Amerika Serikat saat itu. Hal inilah yang menjadi alasan kuat untuk menyatakan adanya kepentingan khusus diantara PMC Academi dan Pemerintah Amerika Serikat, sehingga tak heran mereka selalu hadir dalam setiap konflik Amerika khususnya di Iraq tahun 2004-2007. Kiprah PMC Academi dan PMC yang lain didukung oleh kebutuhan AS dan negara barat lain yang khususnya membutuhkan SDA seperti minyak bumi dan gas alam dikarenakan untuk mendapatkan itu, semua negara tersebut membutuhkan konflik dan perang dengan segala macam alasan.

Dengan adanya kelompok-kelompok elit yang mampu mempengaruhi kebijakan politik luar negeri AS sebut saja kelompok elit yang kaya yang terkadang berbentuk industri militer berbasis bisnis politik, merupakan bisnis persenjataan dan jasa keamanan yang memiliki hubungan dekat dengan para elit politik dalam pemerintahan AS sehingga mampu mempengaruhi elit politik dalam

\footnotetext{
${ }^{29}$ Lihat http://www.bbc.co.uk/indonesian/news/story/2003/11/printable/031103 usa.shtml diakses pada tanggal 11 Desember 2016 pukul 15.30 WIB
} 
pengambilan kebijakan politik luar negeri dan mendapatkan kontrak dalam invasi maupun pasca invasi yang sudah tentu mampu meraup keuntungan yang sangat besar.

Dari kasus dan hasil analsisis tersebut penulis dapat memberikan saran: Untuk dunia internasional agar tidak menggunakan PMC atau perusahaan militer swasta manapun dalam konflik yang mereka lakukan karena dikhawatirkan ada kepentingan khusus yang dijalankan oleh PMC tersebut, atau bisa saja PMC tersebutlah yang menjadi penyerang balik bagi negara penyewanya karena tidak pernah tau nilai historis dan kedekatan apa yang telah mereka miliki, jangan sampai negara yang menyewa ataupun konflik menjadi lahan untuk bisnis mereka agar tetap tumbuh subur.

Untuk masyarakat Internasional agar lebih melihat suatu permasalahan konflik bukan hanya dari penyebab utama yang di beritakan saja tetapi melihat sebuah permasalahan dari sisi lain yang lebih mendalam terkhususkan melalui nilai historis dari aktor-aktor konflik yang terlibat.

Untuk Dewan Keamanan PBB untuk mengevaluasi tentang keberadaan PMC dalam setiap konflik atau peperangan yang ada di dunia serta lebih memperketat tentang aturan yang melibatkan PMC itu di dalamnya.

\section{Daftar Pustaka}

Abdul Halim Mahally. 2003. Membongkar Ambisi Global Amerika Serikat. Jakarta: Pustaka Sinar Harapan.

F.Apter, David. 1996. Pengantar Analisa Politik. Jakarta: LP3ES

Hannah, Jones. 2011. State Control Over Private Millitary and Security Companies in Armed Conflict.

Irving M. Zeitlin. 2002. Memahami Kembali Sosiologi. Yogyakarta: Gajah Mada University Press.

Jeremy Scahill. 2010. BLACKWATER Membongkar Keterlibatan Tentara Bayaran Dalam Invasi Militer Amerika Serikat. Bandung: PT Mizan Pustaka.

Kamus Besar Bahasa Indonesia. 2005. Jakarta: Balai Pustaka

Mancini, F.2005. In Good Company? The Role of Business in Security Sector Reform. London : Demos 
Minaar, A.2007.Oversight and Monitoring of Non-State/Private Policing: Dealing with Misconduct, Use of Force and Criminal Activities by Private Security Practitioners in South Africa', Regulation of the Private Security Sector in Africa. Pretoria:Institute for Security Studies

Mustofa Abdul Rahman. 2003. Geliat Irak Menuju Era Pasca-Saddam. Jakarta: Kompas Media Nusantara

Organisation for Economic Co-operation and Development (OECD).2007.OECD DAC Handbook on Security System Reform, Supporting Security and Justice. Paris:OECD Publishing

Rahmawati,Restu. 2013.Perspektif Ekofeminisme dalam Pengembangan Kawasan Industri Cilacap di Kabupaten Cilacap" Yogyakarta:Pintal

Sabrina, Schulz .2008. Perusahaan Militer dan Swasta dan Gender. Jakarta: DCAF, OSCE/ODIHR, UN-INSTRAW

Setiadi,Elly. 2011. Pengantar Sosiologi Pemahaman Fakta dan Gejala Permasalahan Sosial: Teori, Aplikasi, dan Pemecahannya. Jakarta: Kencana Prenada Media Group.

S Arikunto.2002.Pengantar Statistika.Jakarta:Rineka Cipta

Siti Mutiah Setiawati, dkk. 2004. Irak Di Bawah Kekuasaan Amerika. Yogyakarta: Pusat Pengkajian Masalah Timur Tengah.

Soerjono Soekanto. 2003. Kamus Sosiologi.Jakarta: PT. Raja Grafindo Persada

$\underline{\text { Skripsi }}$

Achmad Muflichin dalam Skripsi Penggunaan PMC dalam Invansi Amerika Serikat Ke Iraq Tahun 2003 UMM: Malang

Tegar Punang Mahardi dalam Skripsi Analisa Penggunaan Private Military Companies (PMCs) Oleh Amerika Serikat Pada Studi Kasus Invasi Amerika Serikat ke Irak Tahun 2009-2011 UMM: Malang

$\underline{\text { Website }}$

http://historia.id/buku/blackwater-tentara-bayaran-paman-sam ditulis oleh Jurnalis Hendri F Isnaeni pada tahun 2010 diakses tanggal 31 Desember 19.23 WIB.

https://www.academi.com/pages/about-us di akses tanggal 30 Desember 2016 Pukul 18.00.

http://www.cnnindonesia.com/internasional/20141023103550-134-7583/tentarablackwater-bersalah-bunuh-warga-irak/ diakses tanggal 7 Desember 2016 pukul 17.30 WIB 
http://www.cnnindonesia.com/internasional/20141024112048-134-7793/tentarabayaran-berkedok-petugas-keamanan/ diakses tanggal 7 Desember 2016 pukul 17.30 WIB

http://chromler.com/blog/10-negara-dengan-militer-terkuat-di-dunia/ diakses tanggal 9 Desember 2016 pukul 17.30 WIB

http://international.sindonews.com/read/928218/43/tentara-bayaran-inggrishabisi-8-militan-isis-per-hari-1416804323 diakses tanggal 9 Desember 2016 pukul 19.30 WIB

http://www.globalsecurity.org/military/world/para/pmc-list.htm diakses tanggal 9 Desember 2016 pukul 19.00 WIB

http://tribunindo.com/10-perusahaan-manufaktur-senjata-terbesar-di-dunia/ diakses tanggal 9 Desember 2016 pukul 19.00 WIB

http://www.bbc.co.uk/indonesian/news/story/2003/11/printable/031103_usa.shtml diakses pada tanggal 11 Desember 2016 pukul $15.30 \mathrm{WIB}$

http://www.privatemilitary.org/definition.html diakses pada tanggal 11 Desember 2016 pukul $15.30 \mathrm{WIB}$

http://chromler.com/blog/10-negara-dengan-militer-terkuat-di-dunia/ diakses tanggal 9 Desember 2016 pukul 17.30 WIB 